August 29, 2011

Steven Feinberg

U.S. Department of Energy

SPRU Field Office SP23

2425 River Road

Niskayuna, New York 12309

DOE CONTRACT NO. DE-AC05-06OR23100

SUBJECT: FINAL REPORT - CHARACTERIZATION SURVEY OF THE SPRU LOWER LEVEL HILLSIDE AREA AT THE KNOLLS ATOMIC POWER LABORATORY, NISKAYUNA, NEW YORK - DCN 5146-SR-01-0

Dear Mr. Feinberg:

Enclosed is the final report of characterization survey activities conducted at the Lower Level Hillside Area by Oak Ridge Institute for Science and Education. This final report addresses and incorporates comments that were provided by the Department of Energy at the Separations Process Research Unit project office.

You may contact me via my information provided below or Phyllis Weaver at 865.576 .5321 should you have any questions or require additional information.

Sincerely,

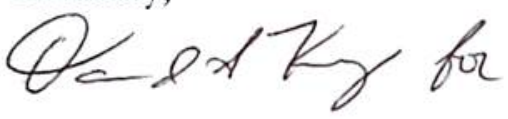

Evan M. Harpenau

Assistant Project Manager/Health Physicist

Independent Environmental Assessment and Verification

$\mathrm{EMH}: \mathrm{bj}$

Enclosure

c: $\quad$ File $/ 5146$

electronic distribution: $\quad$ P. Weaver, (ORISE) E. Bailey, (ORISE)

T. Vitkus, (ORISE) S. Roberts, (ORISE) 


\title{
FINAL REPORT - CHARACTERIZATION SURVEY OF THE SPRU LOWER LEVEL HILLSIDE AREA AT THE KNOLLS ATOMIC POWER LABORATORY, NISKAYUNA, NEW YORK
}

\author{
E. M. Harpenau
}

Prepared for the

U.S. Department of Energy

\section{O R I S E}

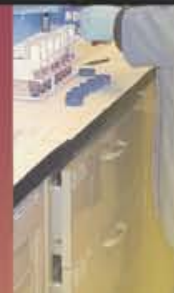

Oak Ridge Institute for Science and Education

Approved for public release; further dissemination unlimited. 
The Oak Ridge Institute for Science and Education (ORISE) is a U.S. Department of Energy institute focusing on scientific initiatives to research health risks from occupational hazards, assess environmental cleanup, respond to radiation medical emergencies, support national security and emergency preparedness, and educate the next generation of scientists. ORISE is managed by Oak Ridge Associated Universities.

\section{NOTICES}

The opinions expressed herein do not necessarily reflect the opinions of the sponsoring institutions of Oak Ridge Associated Universities. This report was prepared as an account of work sponsored by the United States Government. Neither the United States Government nor the U.S. Department of Energy, nor any of their employees, makes any warranty, expressed or implied, or assumes any legal liability or responsibility for the accuracy, completeness, or usefulness of any information, apparatus, product, or process disclosed, or represents that its use would not infringe on privately owned rights. Reference herein to any specific commercial product, process, or service by trade name, mark, manufacturer, or otherwise, does not necessarily constitute or imply its endorsement or recommendation, or favor by the U.S. Government or any agency thereof. The views and opinions of authors expressed herein do not necessarily state or reflect those of the U.S. Government or any agency thereof. 


\section{CHARACTERIZATION SURVEY OF THE SPRU LOWER LEVEL HILLSIDE AREA AT THE KNOLLS ATOMIC POWER LABORATORY, NISKAYUNA, NEW YORK}

Prepared by:

E. M. Harpenau, Assistant Project Manager

Independent Environmental Assessment and Verification

Reviewed by:

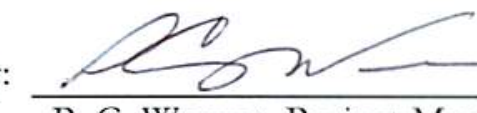

P. C. Weaver, Project Manager

Independent Environmental Assessment and Verification

Reviewed by:

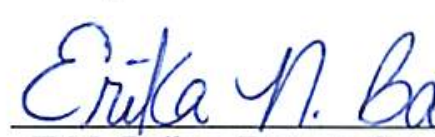

E.N. Bailey, Deputy Survey Pr $\varnothing$ jects Manager

Independent Environmental sssessment and Verification

Reviewed by:

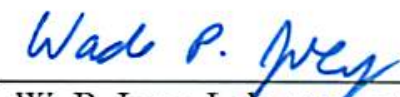

W. P. Ivey, Laborafory Group Manager Independent Environmental Assessment and Verification

Reviewed by:

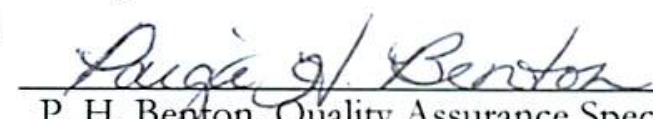

P. H. Benton, Quality Assurance Specialist

Independent Environmental Assessment and Verification
Date:

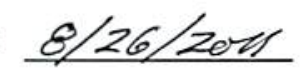

Date: $8 / 24 / 2011$

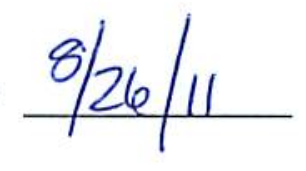

Date:

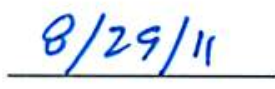

Date:

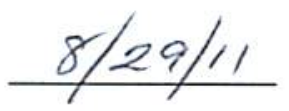




\title{
CHARACTERIZATION SURVEY OF THE \\ SPRU LOWER LEVEL HILLSIDE AREA \\ AT THE KNOLLS ATOMIC POWER LABORATORY, NISKAYUNA, NEW YORK
}

\author{
Prepared by \\ E. M. Harpenau \\ Oak Ridge Institute for Science and Education \\ Oak Ridge, Tennessee 37831-0117 \\ Prepared for the \\ U.S. Department of Energy
}

FINAL REPORT

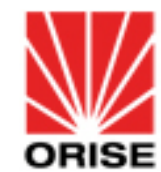

AUGUST 2011

This report is based on work performed by the Oak Ridge Institute for Science and Education under contract number DE-AC05-06OR23100 with the U.S. Department of Energy 


\section{TABLE OF CONTENTS}

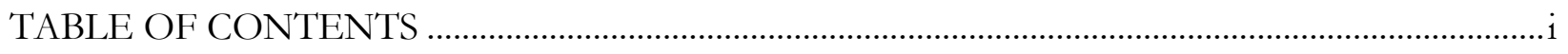

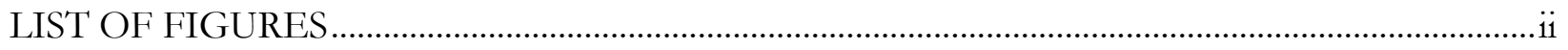

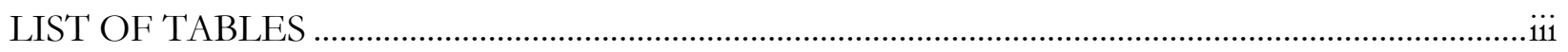

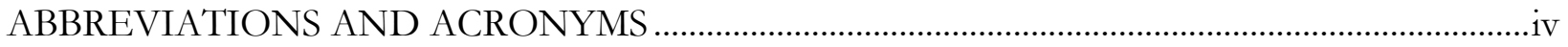

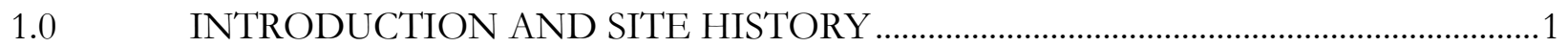

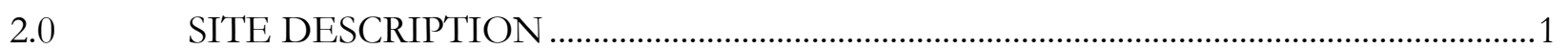

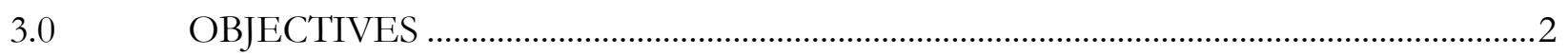

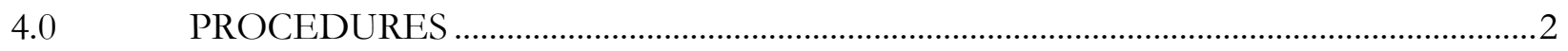

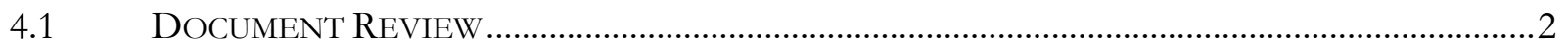

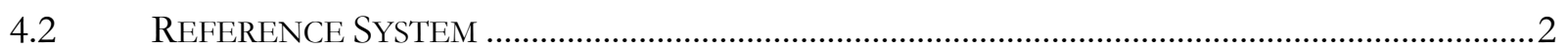

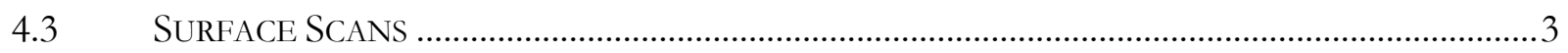

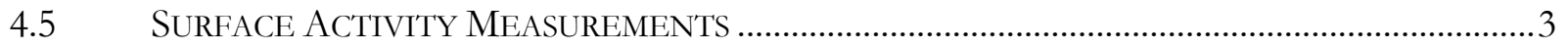

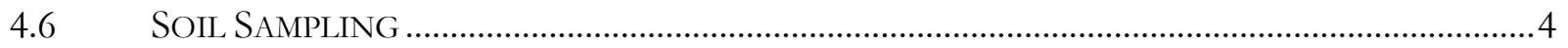

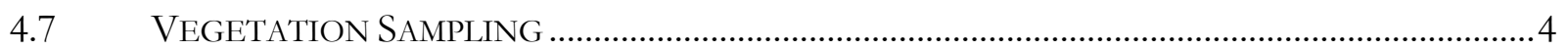

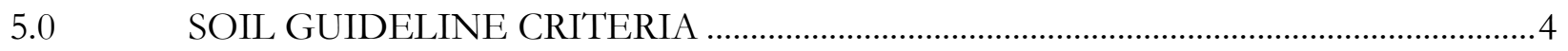

6.0 SAMPLE ANALYSIS AND DATA INTERPRETATION ................................................

FINDINGS AND RESULTS

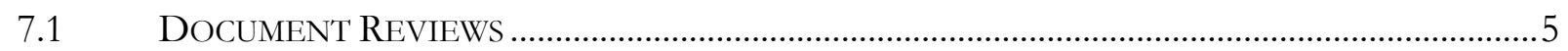

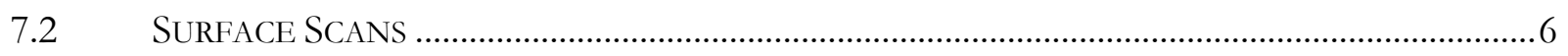

7.4 SOIL ANALYSIS ............................................................................................................

COMPARISION OF RESULTS WITH GUIDELINES

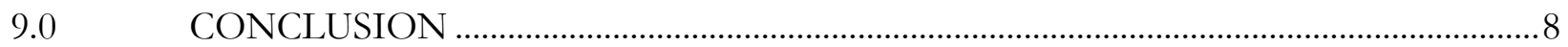

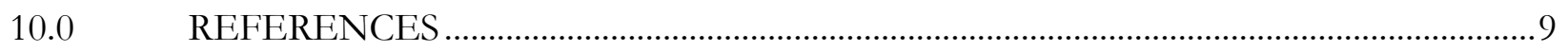

APPENDIX A: FIGURES

APPENDIX B: TABLES

APPENDIX C: MAJOR INSTRUMENTATION

APPENDIX D: SURVEY AND ANALYTICAL PROCEDURES 


\section{LIST OF FIGURES}

Figure A-1: Separations Process Research Unit (SPRU) at the Knolls Atomic Power

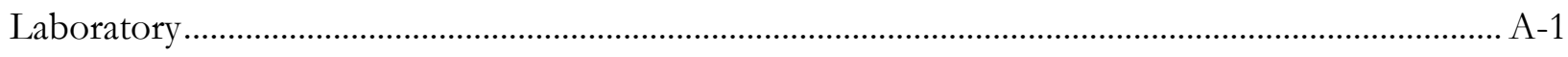

Figure A-2: SPRU Plot Plans for the Lower Level Hillside Area ....................................................... A-2

Figure A-3: SPRU Lower Level Hillside Characterization Area ........................................................... A-3

Figure A-4: Lower Level Hillside Area Surface Scans with 2x2 Detector......................................... A-4

Figure A-5: Soil Sample Locations for the Lower Level Hillside Area............................................... A-5

Figure A-6: Vegetation Sample Locations for the Lower Level Hillside Area ................................... A-6 


\section{LIST OF TABLES}

Table 1: Soil Cleanup Levels for the Radionuclides of Concern ..........................................................5

Table B-1: Surface Activity Measurements Lower Level Hillside Area ...............................................-1

Table B-2: Radionuclide Concentration in Soil Lower Level Hillside Area ............................................4

Table B-3: Radionuclide Concentration in Vegetation Lower Level Hillside Area ...............................6 


\section{ABBREVIATIONS AND ACRONYMS}

\begin{tabular}{|c|c|}
\hline ALARA & as low as reasonably achievable \\
\hline $\mathrm{BKG}$ & background \\
\hline $\mathrm{COC}$ & constituents of concern \\
\hline cpm & counts per minute \\
\hline CSAP/FSS & Confirmation Sample Analysis Plan/Final Status Survey \\
\hline DCGL & derived concentration guideline level \\
\hline DOE & U.S. Department of Energy \\
\hline dpm & disintegrations per minute \\
\hline EM & Environmental Management \\
\hline FSS & final status survey \\
\hline GPS & Global Positioning System \\
\hline ISM & Integrated Safety Management \\
\hline ISOCS & In-Situ Object Counting System \\
\hline ITP & Intercomparison Testing Program \\
\hline IV & independent verification \\
\hline JHA & Job Hazard Analyses \\
\hline KAPL & Knolls Atomic Power Laboratory \\
\hline$\mu \mathrm{g} / \mathrm{kg}$ & microgram per kilogram \\
\hline LLLA & Lower Level Land Area \\
\hline LLHA & Lower Level Hillside Area \\
\hline MAPEP & Mixed Analyte Performance Evaluation Program \\
\hline MARSSIM & Multi-Agency Radiation Survey and Site Investigation Manual \\
\hline MDC & minimum detectable concentration \\
\hline $\mathrm{NaI}$ & sodium iodide \\
\hline NFP & North Field Project \\
\hline NIST & National Institute for Standards and Technology \\
\hline NRIP & National Radiochemistry Intercomparison Program \\
\hline ORAU & Oak Ridge Associated Universities \\
\hline ORISE & Oak Ridge Institute for Science and Education \\
\hline $\mathrm{pCi} / \mathrm{g}$ & picocuries per gram \\
\hline PSP & project-specific plan \\
\hline QAPP & Quality Assurance Project Plan \\
\hline RCRA & Resource Conservation and Recovery Act \\
\hline $\mathrm{ROC}$ & radionuclide of concern \\
\hline
\end{tabular}




\section{ABBREVIATIONS AND ACRONYMS}

RSS ranked set sampling

SCOs Soil Cleanup Objectives

SOF sum of fractions

SPRU Separations Process Research Unit

TAP total absorption peak

VSP Visual Sample Plan 


\section{CHARACTERIZATION SURVEY OF THE SPRU LOWER LEVEL HILLSIDE AREA AT THE KNOLLS ATOMIC POWER LABORATORY, NISKAYUNA, NEW YORK}

\subsection{INTRODUCTION AND SITE HISTORY}

The Separations Process Research Unit (SPRU) is located within the boundary of Knolls Atomic Power Laboratory (KAPL) at 2425 River Road, Niskayuna, Schenectady County, New York (Figure A-1). SPRU was designed and developed to research an efficient process to chemically separate plutonium and uranium from processed fuel. Buildings H2 and G2 were the primary research and process facilities. SPRU operated between February 1950 and October 1953 at which time the research was successful in developing useable reduction oxidation and plutonium-uranium extraction processes. These processes were subsequently moved to the Hanford and the Savannah River sites for full-scale operations. Building H2 was used by KAPL after the SPRU process ceased until the late 1990s for radioactive wastewater processing and Building G2 was utilized for offices. Process areas and equipment were maintained in a safe condition under a surveillance and maintenance program.

An airborne release of radioactive material occurred during demolition activities at Building $\mathrm{H} 2$ on September 29, 2010. This event may have potentially resulted in the contamination of portions of a nearby hillside located to the east and slightly north of the SPRU site. The U.S. Department of Energy Office of Environmental Management (DOE-EM) SPRU Project Office requested support from the Oak Ridge Institute for Science and Education (ORISE) to conduct characterization surveys and determine the environmental impact to the Lower Level Hillside Area (LLHA) as a result of the radiological release.

\subsection{SITE DESCRIPTION}

The LLHA is bounded by the H2 and G2 Building complex and KAPL facilities to the south and the Lower Level Rail Bed to the east (Figure A-2). Although there are approximately 7 acres that make up the LLHA, the primary area of concern consists of approximately 2.9 acres. The LLHA is a narrow band of land that is relatively clear of timber growth but has dense ground cover vegetation (Figure A-3). The hillside area was previously considered as a Class 3 area, per the contamination 
potential definitions provided in the Multi-Agency Radiation Survey and Site Investigation Manual (MARSSIM), based on its position to the site. However, as a result of the event, the area will be classified as a Class 1 (NRC 2000).

\subsection{OBJECTIVES}

The objectives of the characterization surveys were to identify and quantify radioactive contamination within the LLHA by evaluating the soils and natural vegetation and to bound or outline areas of contamination.

\subsection{PROCEDURES}

ORISE site preliminary characterization activities were performed during the period of May 31, 2011 through June 3, 2011. Survey activities were conducted in accordance with the project-specific plan (PSP), ORISE Survey Procedures Manual, and Oak Ridge Associated Universities (ORAU) Quality Program Manual (ORISE 2011a, 2008, and ORAU 2011a). ORISE activities included gamma walkover scans, beta activity scans and static measurements, systematic and judgmental soil sample collection, and vegetation sample collection.

\subsection{DOCUMENT REVIEW}

ORISE reviewed the DOE-EM Type-B Investigation Report (DOE 2010), for pertinent information to aid in the development of the PSP. Air sample data evaluated as part of the DOE investigation identified strontium-90 (Sr-90) as the primary radionuclide of concern (ROC) in quantities 50-60 times that of cesium-137 (Cs-137) (DOE 2010). No other reference documents pertaining to this event were available for review.

\subsection{REFERENCE SYSTEM}

ORISE used a global positioning system (GPS) for documenting survey area boundaries, tracking survey data, and identifying measurement and sampling locations. GPS units were integrated with the ratemeter-scaler and detector to collect position and count rate data. The specific geographic coordinate system required for documentation was the New York State Plane Coordinate System. GPS coordinates are typically accurate to within one meter of any given position data point. The initial LLHA boundary was determined during a site walkdown. Figures from previous ORISE independent verification surveys aided in defining the area of concern. However, as the survey 
progressed, the survey area boundaries had to be altered from the original schematic.

\subsection{SURFACE SCANS}

High-density scans for gamma radiation were performed using a 2 -inch $\times 2$-inch $(2 \times 2)$ sodium iodide $(\mathrm{NaI})$ scintillation detector in the accessible areas of the LLHA. Detectors were coupled to a ratemeter-scaler with audible output. Locations of elevated direct gamma radiation levels were identified in real-time via the audio output and after reviewing the electronic data for anomalies. The GPS signal was occasionally intermittent in certain areas as a result of the tree canopy and dense vegetation. However, the surveyors relied on audible output during scan activities to identify areas for investigation. Gamma scan results are provided in Figure A-4.

Beta scans of the ground surface were performed after the removal of any vegetation coverage. At each sampling point, the beta scans were performed within a contiguous one meter square $\left(1 \mathrm{~m}^{2}\right)$ area from the specified sample point. Measurements were collected using a beta scintillation detector coupled to a ratemeter-scaler with audible output.

\subsection{Statistical SAMPLING Design}

The statistical sampling design used to determine random coordinate locations for measurements and soil sampling was generated using Visual Sample Plan (VSP) software. The combined judgmental and random statistical sampling method was used to determine the number of randomly located samples that should be taken in addition to a predetermined number of judgmental samples which provide a 95 percent confidence that a large fraction of the decision area would be acceptable. Thirty-six random samples were required to achieve the confidence criteria. Adjustments to the VSP survey area design were completed on-site as it was determined that the survey boundaries needed to be modified to provide a more accurate representation.

\subsection{Surface ACtivity Measurements}

Each random coordinate or judgmentally relocated assessment location was evaluated for both beta and gamma emitting isotopes. A one-minute static measurement, in counts per minute (cpm), was recorded with each instrument type prior to and after the collection of a soil sample on the soil surface (Table B-1). Gamma static measurements were obtained using the $\mathrm{NaI}$ detector and beta static measurements were obtained using the beta scintillation detector. 


\subsection{SOIL SAMPLING}

Surface soil samples ( 0 to $5 \mathrm{~cm}$ ) were collected at the assessment locations provided in Figure A-5. Four of the 36 locations measured were relocated due to inaccessibility caused by steep terrain and locations outside the perimeter fence. These four judgmental samples, $5146 \mathrm{~S} 0033$ through 5146S0036, were relocated to assess surfaces with a higher potential for contamination run-off and that exhibited the maximum gamma activity levels observed during scans.

\subsection{VEGETATION SAMPLING}

Vegetation was collected at twelve judgmentally selected locations with regard to run-off collection areas and along the tree lines (Figure A-6). A variety of vegetation was provided for analysis. Eleven of the twelve samples were collected at predetermined soil assessment locations. The twelfth vegetation sample was selected based on its direct correlation with the water run-off pathway from the H2 Building.

\subsection{SOIL GUIDELINE CRITERIA}

Soil derived concentration guideline levels (DCGLs) for the site's ROC previously established for the SPRU project are provided in Table 1 (URS 2010). The most prominent ROC identified for this survey is Sr-90 at concentrations 50-60 times that of Cs-137. The DCGL approved as the SPRU project cleanup goal for Sr-90 is $4.82 \mathrm{E}+03 \mathrm{pCi} / \mathrm{g}$. However, DOE-EM at SPRU has implemented an as low as reasonably achievable (ALARA) cleanup goal for $\mathrm{Sr}-90$ concentrations at $30 \mathrm{pCi} / \mathrm{g}$, which is less than 1\% of the site's DCGL (DOE 2011). This is the volumetric activity within the first $15 \mathrm{~cm}$ of soil that corresponds with the $25 \mathrm{mrem} / \mathrm{yr}$ unrestricted use criterion. The actual concentrations identified will be used to determine the appropriate MARSSIM classification and whether further action is required.

\subsection{SAMPLE ANALYSIS AND DATA INTERPRETATION}

Samples were returned to the ORISE laboratory in Oak Ridge, TN for radiological analysis and interpretation. Sample analyses were performed in accordance with the ORISE Laboratory Procedures Manual (ORISE 2011b). Soil and vegetation samples were analyzed by gamma spectroscopy and reviewed for Cs-137 peaks as well as any other gamma-emitting radionuclides. The dominant ROC identified, Sr-90, was quantified by radiochemical separation and counted on a low 
background proportional counter. Analytical results are reported in units of picocuries per gram (pCi/g). These results were then compared to the DCGLs or ALARA goals provided in Table 1.

Gamma spectroscopy spectra were reviewed to identify other photopeaks that could contribute to the total radionuclide concentration. Gamma spectroscopy results for americium-241 (Am-241) were also reviewed because it is a decay product of plutonium-241 (Pu-241). A high concentration of Am-241 would be indicative that alpha spectroscopy was warranted to quantify plutonium levels.

\begin{tabular}{|c|c|c|c|}
\hline \multicolumn{4}{|c|}{$\begin{array}{c}\text { TABLE 1: } \\
\text { SOIL CLEANUP LEVELS FOR THE } \\
\text { RADIONUCLIDES OF CONCERN } \\
\text { SEPARATIONS PROCESS RESEARCH UNIT } \\
\text { NISKAYUNA, NEW YORK }\end{array}$} \\
\hline ROC & DCGL (pCi/g) & ROC & DCGL (pCi/g) \\
\hline Am-241 & 595 & Pu-241 & 20,060 \\
\hline Cs-137 & 30 & Sr-90 & $4,826^{a}$ \\
\hline Co-60 & 10.3 & Th-232 & 9.5 \\
\hline $\mathrm{Pu}-238$ & 818 & $\mathrm{U}-234$ & 767 \\
\hline Pu-239 & 737 & U-235 & 196 \\
\hline $\mathrm{Pu}-240$ & 738 & $\mathrm{U}-238$ & 896 \\
\hline
\end{tabular}

${ }^{a}$ DOE-EM implemented an ALARA cleanup goal of 30pCi/g for Sr-90

\subsection{FINDINGS AND RESULTS}

The results of the characterization surveys for the LLHA are discussed in the following sections. Direct measurement and radionuclide concentration data for all samples are provided in Tables B-1 through B-3.

\subsection{DOCUMENT REVIEWS}

The DOE-EM Investigation Report served as the primary reference document for developing the characterization survey approach (DOE 2010). The Radiological Confirmation Sampling and Analysis Plan/Final Status Survey (CSAP/FSS) for the Separations Process Unit Upper Level Land Area also provided soil cleanup levels for the ROCs expected to be encountered during the characterization of the hillside (URS 2010). 


\subsection{SURFACE SCANS}

ORISE performed gamma scans of the accessible areas in the LLHA. Areas that were particularly clear of vegetation received a higher density scan. Steep terrain and heavy vegetation greatly impeded movement of the detector and inhibited access. This was a factor in trying to survey the gulley area that spanned the gap between two wooded regions. The assumed LLHA boundary incorporated a part of the wooded region closest to the nearby access road. Surveys were limited there because the dense tree canopy interfered with GPS tracking ability and the terrain in the eastern wooded region was too hazardous to perform walkover surveys. The inaccessibility of the eastern wooded region and perimeter fence prevented the randomly distributed samples 5146S0033 through 5146S0036 from being collected. These samples were relocated to other locations based on professional observation and scan information.

Gamma walkover surveys identified a few isolated areas with radioactivity slightly greater than twice background. The areas identified as exhibiting elevated activity received additional investigative scans. The gamma scan range observed was approximately 9,000 to 17,700 gross cpm and the ambient background averaged around 7,000 cpm. Of the four relocated soil samples, two were collected from locations that exhibited elevated gamma radiation levels at the bottom of the hillside (Figure A-5).

The a priori scan minimum detectable concentration (MDC) for a $2 \times 2$ detector is approximately 6.4 pCi/g for the secondary ROC Cs-137 (estimated from Table 6.4 of NUREG-1507)(NRC 1997). Therefore, the detector was capable of determining Cs-137 concentrations lower than the site specific DCGL of $30 \mathrm{pCi} / \mathrm{g}$.

At each soil assessment location, a beta scintillation detector was used to perform scans within the immediate $1 \mathrm{~m}^{2}$ area around the measurement location. Beta scans typically ranged from approximately 300 to 600 gross cpm. The average ambient beta background was determined to be $349 \mathrm{cpm}$. An area unaffected by site activities was selected to determine the average ambient background using 10 one minute counts. 


\subsection{Surface ACtivity MEASUREMENTS}

The result of static surface activity measurements are provided in Table B-1. Sample 5146S0035 had the highest background corrected beta activity at 1,347 disintegrations per minute (dpm) per $100 \mathrm{~cm}^{2}$ and the highest gamma activity at 15,780 cpm. Sample 5146 S0026 had the second highest background corrected beta activity at $956 \mathrm{dpm} /$ per $100 \mathrm{~cm}^{2}$. With the exception of sample 5146S0035, background corrected beta activity ranged from $266 \mathrm{dpm} /$ per $100 \mathrm{~cm}^{2}$ to $956 \mathrm{dpm} /$ per $100 \mathrm{~cm}^{2}$.

\subsection{SOIL ANALYSIS}

Radionuclide concentrations for soil samples are provided in Table B-2. Concentrations for the primary radionuclide Sr-90 ranged from -0.22 to 0.94 pCi/g. Cs-137 concentrations range from 0.03 to $1.31 \mathrm{pCi} / \mathrm{g}$. Concentrations for U-235 and U-238 ranged from -0.17 to $0.26 \mathrm{pCi} / \mathrm{g}$ and 0.31 to $1.40 \mathrm{pCi} / \mathrm{g}$, respectively, and total uranium ranged from 0.79 to $2.90 \mathrm{pCi} / \mathrm{g}$. Am-241 concentrations ranged from -0.17 to $0.08 \mathrm{pCi} / \mathrm{g}$. All sample spectra were reviewed for other identifiable photopeaks.

\subsection{VEgETATION ANALYSIS}

The analytical results for vegetation samples are provided in Table B-3. Sr-90 concentrations ranged from -0.01 to $1.01 \mathrm{pCi} / \mathrm{g}$ and $\mathrm{C}-137$ concentrations ranged from 0.01 to $0.42 \mathrm{pCi} / \mathrm{g}$. Concentrations for U-235 and U-238 ranged from -0.12 to $0.16 \mathrm{pCi} / \mathrm{g}$ and -0.26 to $0.74 \mathrm{pCi} / \mathrm{g}$, respectively, and total uranium ranged from -0.36 to $1.52 \mathrm{pCi} / \mathrm{g}$. Am-241 concentrations ranged from -0.03 to $0.01 \mathrm{pCi} / \mathrm{g}$.

\subsection{COMPARISION OF RESULTS WITH GUIDELINES}

The final concentrations for the analytes of concern at SPRU's LLHA were well below the respective DCGL values for Sr-90 and for other ROCs that had been associated with the SPRU project. Sample 5146S0035 had the highest static beta and gamma measurements in the field; however, the concentration determined for Sr-90 was $0.27 \mathrm{pCi} / \mathrm{g}$ and Cs-137 was $1.31 \mathrm{pCi} / \mathrm{g}$. Total uranium at this location was $2.44 \mathrm{pCi} / \mathrm{g}$. 


\subsection{CONCLUSION}

During May 31, 2011 through June 3, 2011, ORISE conducted a characterization survey of the Lower Level Hillside Area. The Lower Level Hillside Area, which is the upper portion of the Lower Level Land Area, was impacted during a release of Sr-90 during demolition at the H2 Building originally a part of the Separations Process Research Unit. The survey included beta and gamma scans, static surface measurements at soil sample locations, and sampling of soil and vegetation.

Scans were limited to the area east of the demolition area where vegetative growth such as trees and ground cover were minimal. The amount of vegetative growth coupled with the steep terrain of certain areas made it difficult to access several locations in order to gather scan data and collect samples. Analytical results of the soil and vegetation samples collected by ORISE were all below the applicable derived concentration guideline level or as low as reasonably achievable objectives. 


\subsection{REFERENCES}

Oak Ridge Associated Universities (ORAU). Quality Program Manual for the Independent Environmental Assessment and Verification Program. Oak Ridge, Tennessee. May 10, 2011.

Oak Ridge Associated Universities. ORAU Health and Safety Manual. Oak Ridge, Tennessee. March 24, 2011b.

Oak Ridge Institute for Science and Education (ORISE). Survey Procedures Manual for the Independent Environmental Assessment and Verification Program. Oak Ridge, Tennessee. May 1, 2008.

Oak Ridge Institute for Science and Education. Project-Specific Plan for the Characterization of the Lower Level Hillside Survey Area at the Separations Process Research Unit Niskayuna, New York. Oak Ridge, Tennessee. May 24, 2011a.

Oak Ridge Institute for Science and Education. Laboratory Procedures Manual for the Independent Environmental Assessment and Verification Program. Oak Ridge, Tennessee. April 28, 2011b.

Oak Ridge Institute for Science and Education. Radiation Protection Manual. Oak Ridge, Tennessee. February 14, 2011c.

United Research Services Corporation (URS). Radiological Confirmation Sampling and Analysis Plan/Final Status Survey (CSAP/FSS) for the Separations Process Unit Upper Level Land Area. Niskayuna, New York. May 27, 2010.

U.S. Department of Energy (DOE). Type B Accident Investigation Report. Radiological Contamination Event During Separations Process Research Unit Building H2 Demolition. November 23, 2010.

U.S. Department of Energy. Email from S. Feinberg (DOE-SPRU) to E. Bailey (ORISE); RE: ORISE draft plan for the characterization of the LL Hillside Area. May 18, 2011.

U.S. Nuclear Regulatory Commission (NRC). Minimum Detectable Concentrations with Typical Radiation Survey Instruments for V arious Contaminants and Field Conditions NUREG/CR-1507. Washington D.C. 1997.

U.S. Nuclear Regulatory Commission (NRC). Multi-Agency Radiation Survey and Site Investigation Manual (MARSSIM), NUREG-1575; Revision 1. Washington, DC. August 2000. 


\section{APPENDIX A FIGURES}




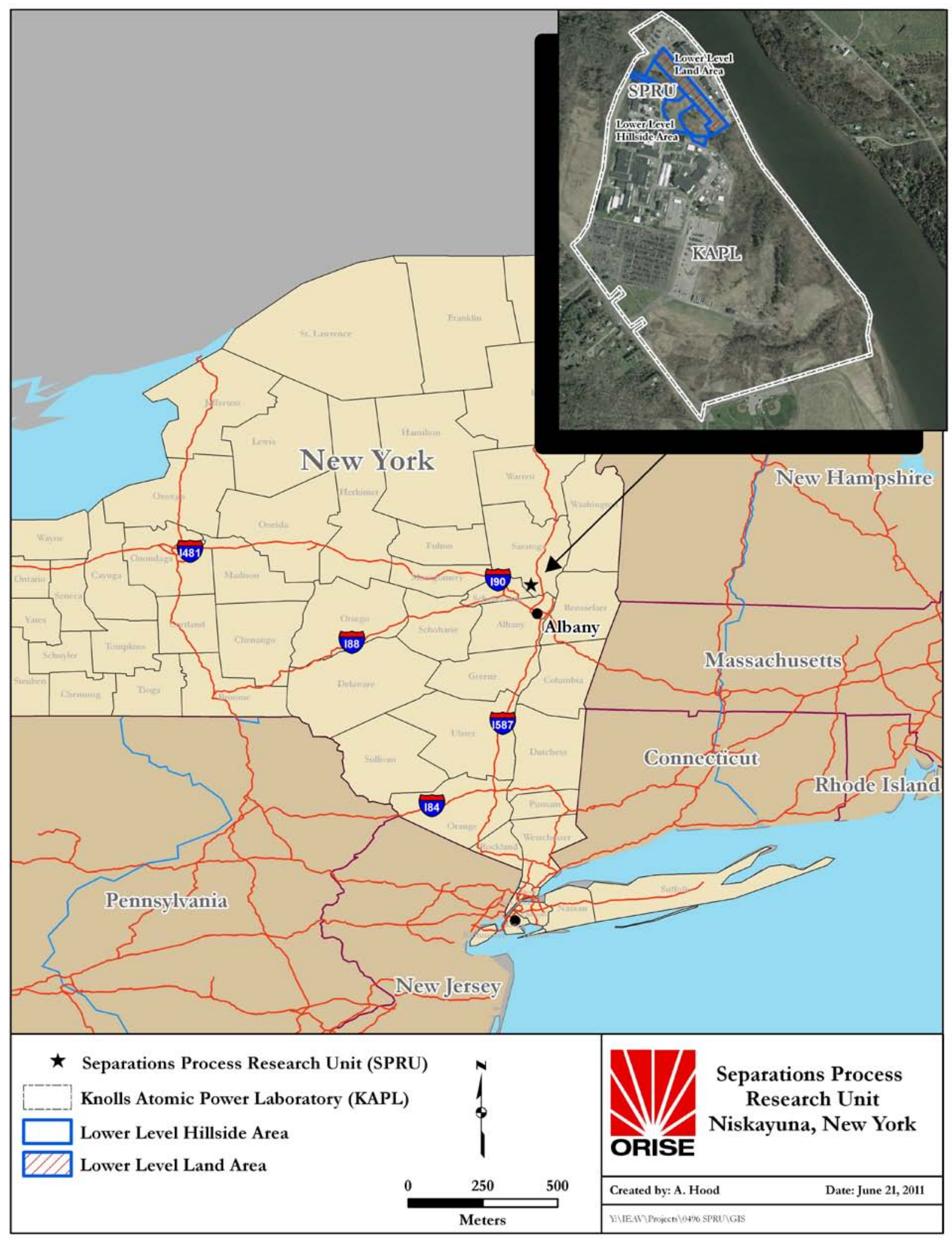

Figure A-1: Separations Process Research Unit (SPRU) at the Knolls Atomic Power Laboratory 


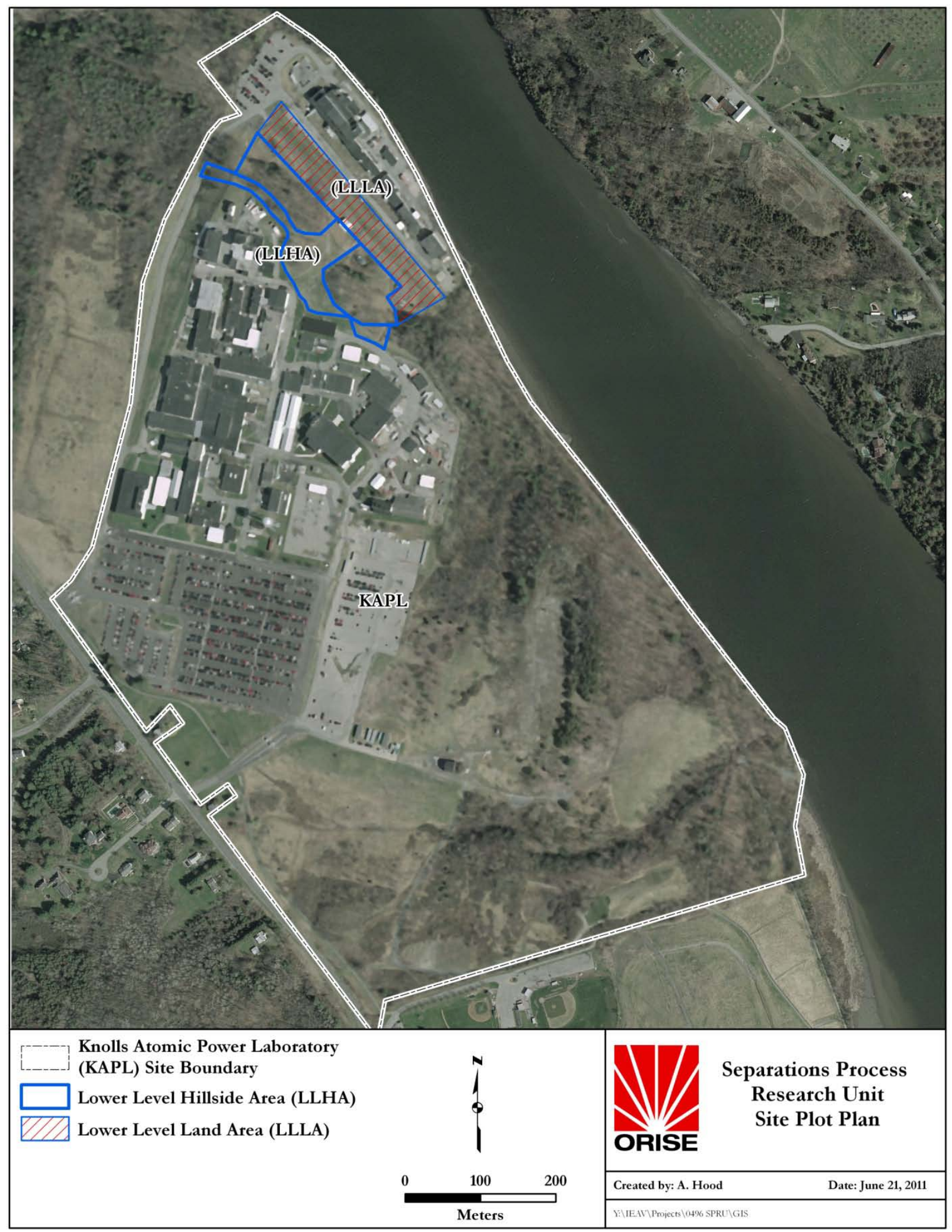

Figure A-2: SPRU Plot Plans for the Lower Level Hillside Area 


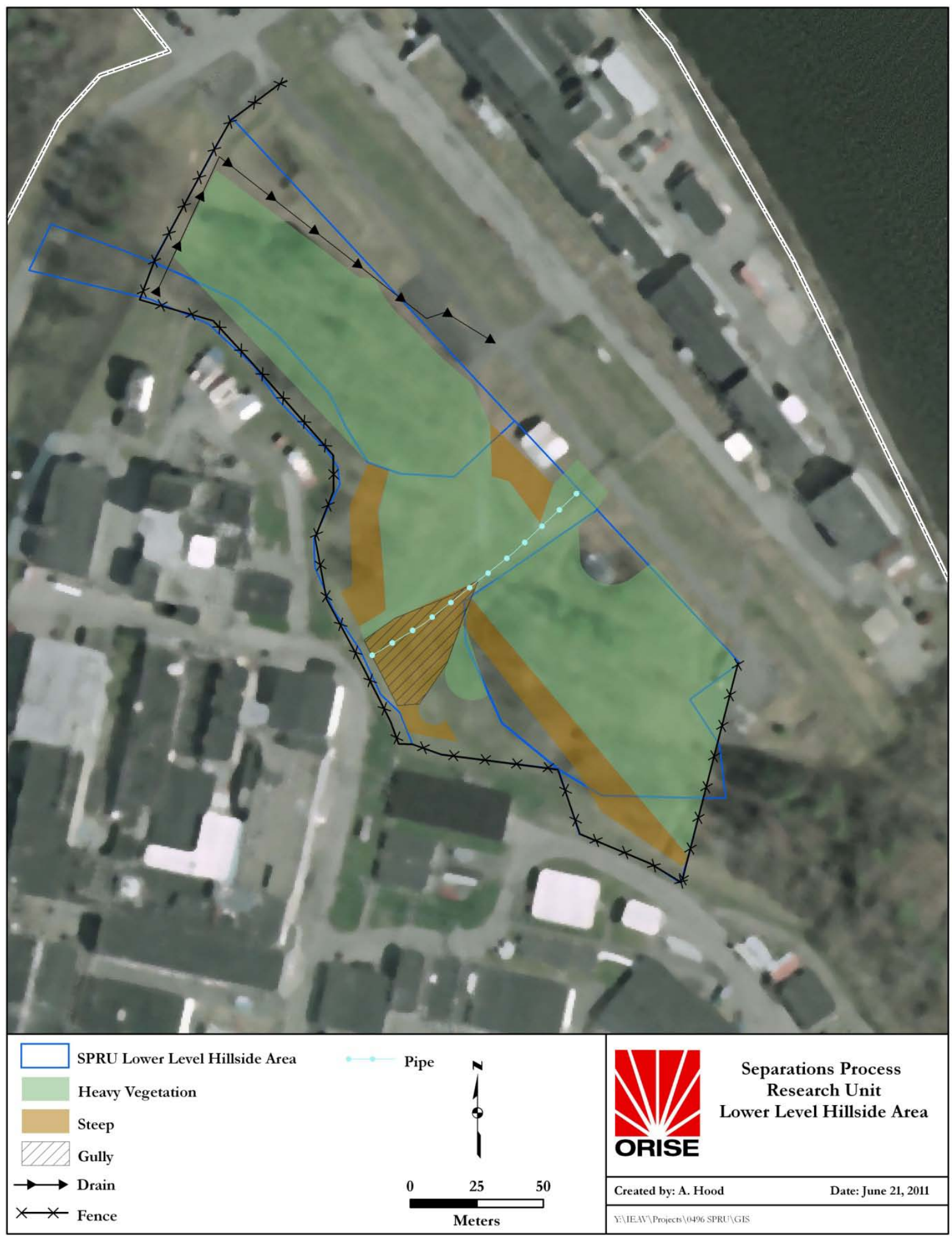

Figure A-3: SPRU Lower Level Hillside Characterization Area 


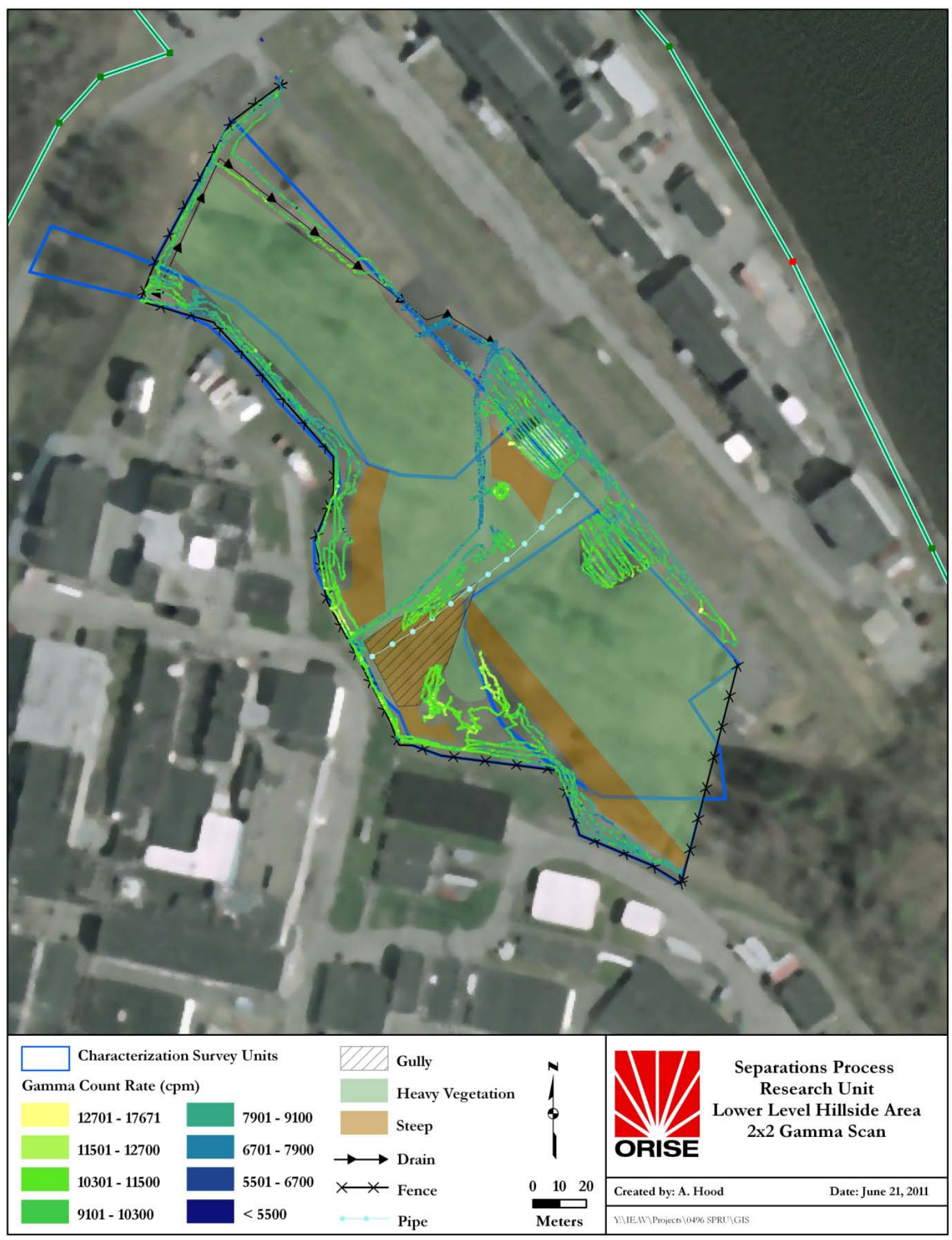

Figure A-4: Lower Level Hillside Area Gamma Surface Scans with 2x2 Detector 


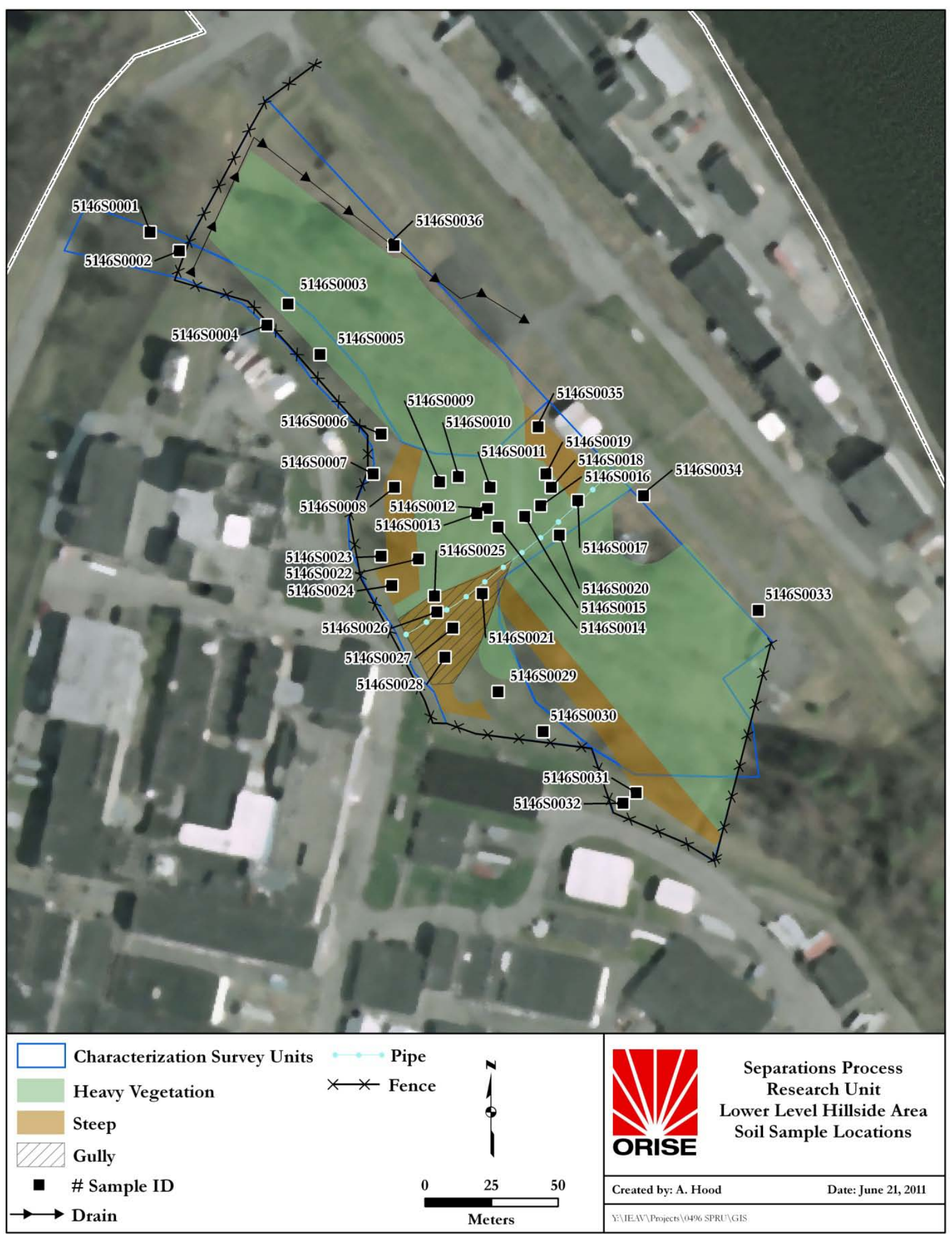

Figure A-5: Soil Sample Locations for the Lower Level Hillside Area 


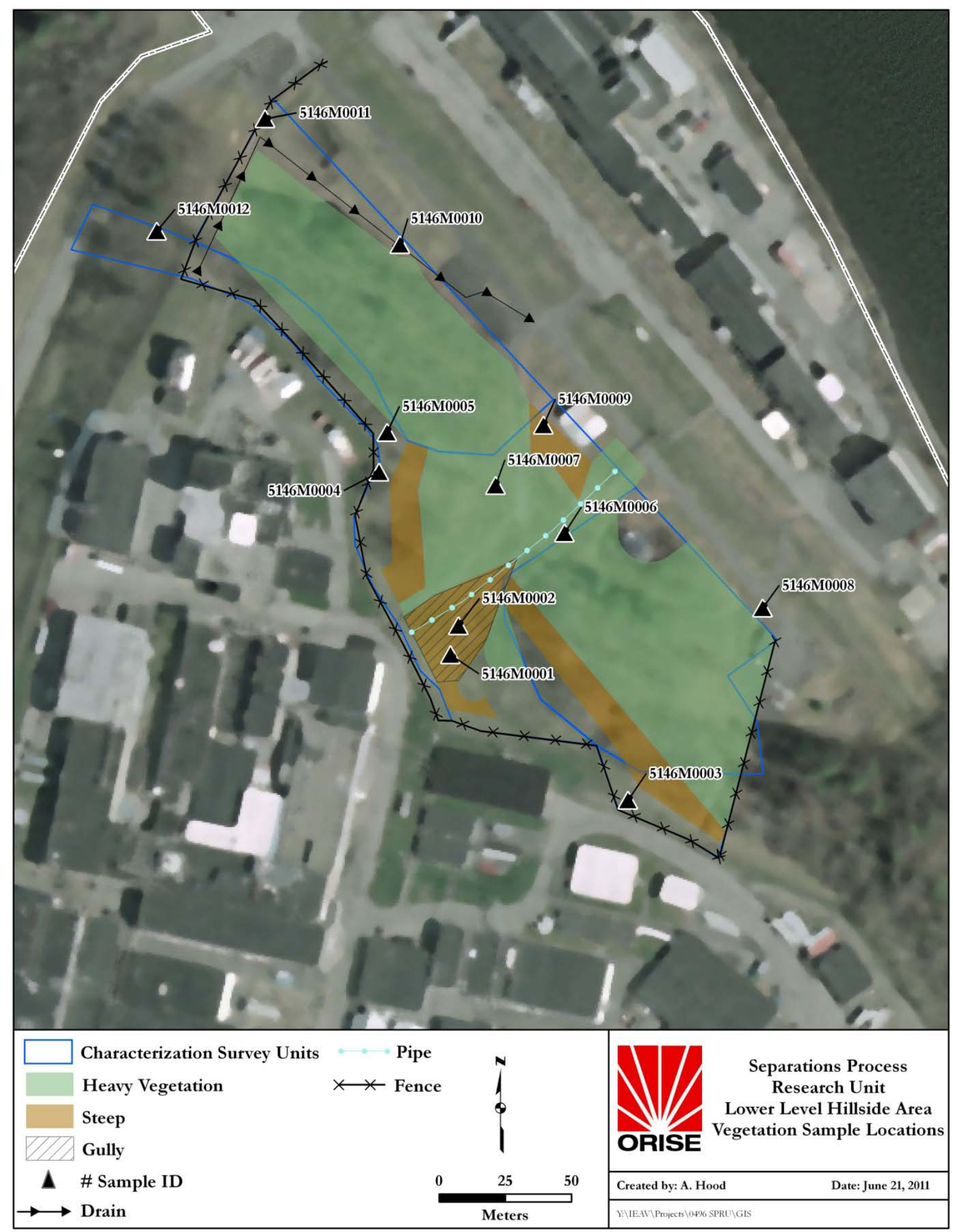

Figure A-6: Vegetation Sample Locations for the Lower Level Hillside Area 


\section{APPENDIX B}

\section{TABLES}




\begin{tabular}{|c|c|c|c|c|c|c|c|}
\hline \multirow{4}{*}{ Location $^{a}$} & \multicolumn{5}{|c|}{$\begin{array}{l}\text { TABLE B-1: } \\
\text { CE ACTIVITY MEASUREMENTS } \\
\text { WER LEVEL HILLSIDE AREA } \\
\text { TIONS PROCESS RESEARCH UNIT } \\
\text { NISKAYUNA, NEW YORK }\end{array}$} & & \\
\hline & \multicolumn{7}{|c|}{ Direct Measurements } \\
\hline & \multicolumn{2}{|c|}{ GPS Coordinates (m) } & \multicolumn{3}{|c|}{ Beta Activity } & \multicolumn{2}{|c|}{ Gamma Radiation } \\
\hline & Easting $^{\mathrm{b}}$ & Northing $^{\mathrm{b}}$ & $\begin{array}{c}\text { Pre-Sample } \\
\text { (cpm) }\end{array}$ & $\begin{array}{c}\text { Post-Sample } \\
\text { (cpm) }\end{array}$ & $\begin{array}{c}\text { Bkg. } \\
\text { Corrected } \\
\left(\mathrm{dpm} / 100 \mathrm{~cm}^{2}\right)\end{array}$ & $\begin{array}{c}\text { Pre-Sample } \\
\text { (cpm) }\end{array}$ & $\begin{array}{c}\text { Post-Sample } \\
\text { (cpm) }\end{array}$ \\
\hline $5146 \mathrm{~S} 0001$ & 624682 & 1029908 & 522 & 565 & 675 & 9,128 & 9,371 \\
\hline $5146 \mathrm{~S} 0002$ & 624718 & 1029885 & 525 & 596 & 772 & 9,575 & 9,638 \\
\hline $5146 \mathrm{~S} 0003$ & 624852 & 1029820 & 572 & 642 & 916 & 9,807 & 10,546 \\
\hline $5146 S 0004$ & 624826 & 1029794 & 435 & 434 & 266 & 8,148 & 9,470 \\
\hline $5146 \mathrm{~S} 0005$ & 624892 & 1029758 & 471 & 522 & 541 & 9,106 & 10,250 \\
\hline $5146 S 0006$ & 624967 & 1029659 & 480 & 472 & 384 & 8,568 & 9,742 \\
\hline $5146 \mathrm{~S} 0007$ & 624957 & 1029610 & 446 & 496 & 459 & 9,006 & 9,875 \\
\hline $5146 \mathrm{~S} 0008$ & 624984 & 1029593 & 490 & 528 & 559 & 9,651 & 9,518 \\
\hline $5146 S 0009$ & 625039 & 1029600 & 477 & 539 & 594 & 9,756 & 9,857 \\
\hline $5146 S 0010$ & 625062 & 1029607 & 502 & 537 & 588 & 9,702 & 10,009 \\
\hline $5146 \mathrm{~S} 0011$ & 625102 & 1029593 & 516 & 511 & 506 & 10,093 & 10,459 \\
\hline $5146 \mathrm{~S} 0012$ & 625098 & 1029567 & 453 & 534 & 578 & 10,797 & 11,039 \\
\hline $5146 \mathrm{~S} 0013$ & 625085 & 1029561 & 531 & 519 & 531 & 9,973 & 10,781 \\
\hline $5146 \mathrm{~S} 0014$ & 625112 & 1029544 & 429 & 505 & 488 & 8,660 & 8,674 \\
\hline
\end{tabular}




\begin{tabular}{|c|c|c|c|c|c|c|c|}
\hline \multirow{4}{*}{ Location } & \multicolumn{5}{|c|}{$\begin{array}{l}\text { TABLE B-1: } \\
\text { ICE ACTIVITY MEASUREMENTS } \\
\text { WER LEVEL HILLSIDE AREA } \\
\text { TIONS PROCESS RESEARCH UNIT } \\
\text { NISKAYUNA, NEW YORK }\end{array}$} & & \\
\hline & \multicolumn{7}{|c|}{ Direct Measurements } \\
\hline & \multicolumn{2}{|c|}{ GPS Coordinates (m) } & \multicolumn{3}{|c|}{ Beta Activity } & \multicolumn{2}{|c|}{ Gamma Radiation } \\
\hline & Easting & Northing & $\begin{array}{c}\text { Pre-Sample } \\
\text { (cpm) }\end{array}$ & $\begin{array}{c}\text { Post-Sample } \\
\text { (cpm) }\end{array}$ & $\begin{array}{c}\text { Bkg. } \\
\text { Corrected } \\
\left(\mathrm{dpm} / 100 \mathrm{~cm}^{2}\right)\end{array}$ & $\begin{array}{c}\text { Pre-Sample } \\
\text { (cpm) }\end{array}$ & $\begin{array}{c}\text { Post-Sample } \\
\text { (cpm) }\end{array}$ \\
\hline $5146 S 0015$ & 625144 & 1029557 & 464 & 437 & 275 & 7,676 & 8,127 \\
\hline $5146 S 0016$ & 625164 & 1029571 & 583 & 564 & 672 & 9,511 & 10,268 \\
\hline $5146 S 0017$ & 625210 & 1029577 & 583 & 523 & 544 & 9,537 & 9,946 \\
\hline $5146 S 0018$ & 625177 & 1029593 & 539 & 547 & 619 & 9,450 & 10,109 \\
\hline $5146 S 0019$ & 625171 & 1029610 & 476 & 532 & 572 & 9,610 & 10,230 \\
\hline $5146 S 0020$ & 625187 & 1029534 & 616 & 619 & 844 & 10,381 & 10,711 \\
\hline $5146 \mathrm{~S} 0021$ & 625092 & 1029462 & 555 & 580 & 722 & 10,655 & 10,765 \\
\hline $5146 \mathrm{~S} 0022$ & 625013 & 1029505 & 556 & 561 & 663 & 10,130 & 10,495 \\
\hline $5146 S 0023$ & 624967 & 1029508 & 545 & 517 & 525 & 10,423 & 11,166 \\
\hline $5146 S 0024$ & 624980 & 1029472 & 546 & 556 & 647 & 10,677 & 11,059 \\
\hline $5146 \mathrm{~S} 0025$ & 625033 & 1029459 & 549 & 549 & 625 & 10,560 & 11,651 \\
\hline $5146 \mathrm{~S} 0026$ & 625036 & 1029439 & 589 & 655 & 956 & 10,677 & 11,284 \\
\hline $5146 \mathrm{~S} 0027$ & 625056 & 1029420 & 486 & 569 & 688 & 9,181 & 9,744 \\
\hline
\end{tabular}




\begin{tabular}{|c|c|c|c|c|c|c|c|}
\hline \multirow{4}{*}{ Location } & \multicolumn{5}{|c|}{$\begin{array}{c}\text { TABLE B-1: } \\
\text { SURFACE ACTIVITY MEASUREMENTS } \\
\text { LOWER LEVEL HILLSIDE AREA } \\
\text { SEPARATIONS PROCESS RESEARCH UNIT } \\
\text { NISKAYUNA, NEW YORK }\end{array}$} & & \\
\hline & \multicolumn{7}{|c|}{ Direct Measurements } \\
\hline & \multicolumn{2}{|c|}{ GPS Coordinates (m) } & \multicolumn{3}{|c|}{ Beta Activity } & \multicolumn{2}{|c|}{ Gamma Radiation } \\
\hline & Easting & Northing & $\begin{array}{c}\text { Pre-Sample } \\
\text { (cpm) }\end{array}$ & $\begin{array}{c}\text { Post-Sample } \\
\text { (cpm) }\end{array}$ & $\begin{array}{c}\text { Bkg. } \\
\text { Corrected } \\
\left(\mathrm{dpm} / 100 \mathrm{~cm}^{2}\right)\end{array}$ & $\begin{array}{c}\text { Pre-Sample } \\
\text { (cpm) }\end{array}$ & $\begin{array}{c}\text { Post-Sample } \\
\text { (cpm) }\end{array}$ \\
\hline $5146 \mathrm{~S} 0028$ & 625046 & 1029384 & 564 & 573 & 700 & 9,933 & 10,392 \\
\hline $5146 \mathrm{~S} 0029$ & 625112 & 1029341 & 567 & 564 & 672 & 11,046 & 11,178 \\
\hline $5146 \mathrm{~S} 0030$ & 625167 & 1029292 & 454 & 522 & 541 & 9,713 & 9,758 \\
\hline $5146 S 0031$ & 625282 & 1029216 & 524 & 502 & 478 & 7,849 & 8,604 \\
\hline $5146 \mathrm{~S} 0032$ & 625266 & 1029203 & 536 & 511 & 506 & 8,898 & 9,363 \\
\hline $5146 S 0033$ & 625431 & 1029439 & 504 & 500 & 472 & 9,873 & 10,460 \\
\hline $5146 S 0034$ & 625291 & 1029583 & 663 & 616 & 834 & 9,310 & 9,940 \\
\hline $5146 \mathrm{~S} 0035$ & 625161 & 1029668 & 799 & 780 & 1,347 & 15,569 & 15,780 \\
\hline $5146 \mathrm{~S} 0036$ & 624983 & 1029892 & 654 & 552 & 634 & 10,758 & 10,722 \\
\hline
\end{tabular}

aRefer to Figure A-5.

bNew York State Plane Coordinate System East 3101 NAD 1927 US Foot. 


\begin{tabular}{|c|c|c|c|c|c|c|}
\hline \multirow{3}{*}{ Sample ID ${ }^{a}$} & \multicolumn{5}{|c|}{$\begin{array}{c}\text { TABLE B-2: } \\
\text { RADIONUCLIDE CONCENTRATION IN SOIL } \\
\text { LOWER LEVEL HILLSIDE AREA } \\
\text { SEPARATIONS PROCESS RESEARCH UNIT } \\
\text { NISKAYUNA, NEW YORK }\end{array}$} & \\
\hline & \multicolumn{6}{|c|}{ Radionuclide Concentration in Soil Samples (pCi/g) } \\
\hline & Sr-90 ${ }^{b}$ & Am-241 & Cs-137 & $\mathrm{U}-235$ & $\mathrm{U}-238$ & Total $\mathbf{U}^{\mathrm{c}}$ \\
\hline $5146 \mathrm{~S} 0001$ & $0.02 \pm 0.47^{\mathrm{d}}$ & $-0.04 \pm 0.07$ & $0.48 \pm 0.06$ & $0.08 \pm 0.15$ & $0.78 \pm 0.32$ & $1.64 \pm 0.66$ \\
\hline $5146 \mathrm{~S} 0002$ & $-0.04 \pm 0.39$ & $-0.02 \pm 0.08$ & $0.46 \pm 0.06$ & $0.08 \pm 0.22$ & $0.61 \pm 0.31$ & $1.30 \pm 0.66$ \\
\hline $5146 \mathrm{~S} 0003$ & $0.00^{\mathrm{e}} \pm 0.43$ & $0.01 \pm 0.06$ & $0.05 \pm 0.02$ & $0.08 \pm 0.17$ & $1.14 \pm 0.29$ & $2.36 \pm 0.60$ \\
\hline $5146 \mathrm{~S} 0004$ & $0.30 \pm 0.49$ & $0.03 \pm 0.06$ & $0.19 \pm 0.03$ & $0.01 \pm 0.12$ & $0.70 \pm 0.28$ & $1.41 \pm 0.57$ \\
\hline $5146 \mathrm{~S} 0005$ & $-0.03 \pm 0.41$ & $0.01 \pm 0.07$ & $0.31 \pm 0.04$ & $0.04 \pm 0.13$ & $1.03 \pm 0.32$ & $2.10 \pm 0.65$ \\
\hline $5146 \mathrm{~S} 0006$ & $0.19 \pm 0.41$ & $0.00 \pm 0.07$ & $0.24 \pm 0.04$ & $0.08 \pm 0.20$ & $0.73 \pm 0.32$ & $1.54 \pm 0.67$ \\
\hline $5146 \mathrm{~S} 0007$ & $-0.17 \pm 0.39$ & $0.04 \pm 0.06$ & $0.34 \pm 0.04$ & $-0.14 \pm 0.17$ & $0.84 \pm 0.25$ & $1.54 \pm 0.53$ \\
\hline $5146 \mathrm{~S} 0008$ & $0.06 \pm 0.41$ & $0.03 \pm 0.07$ & $0.32 \pm 0.05$ & $0.10 \pm 0.14$ & $0.52 \pm 0.66$ & $1.1 \pm 1.3$ \\
\hline $5146 \mathrm{~S} 0009$ & $0.03 \pm 0.44$ & $-0.10 \pm 0.07$ & $0.50 \pm 0.06$ & $0.08 \pm 0.15$ & $0.63 \pm 0.31$ & $1.34 \pm 0.64$ \\
\hline $5146 \mathrm{~S} 0010$ & $0.18 \pm 0.45$ & $0.05 \pm 0.08$ & $0.31 \pm 0.05$ & $0.02 \pm 0.23$ & $1.24 \pm 0.39$ & $2.50 \pm 0.81$ \\
\hline $5146 \mathrm{~S} 0011$ & $0.32 \pm 0.45$ & $0.05 \pm 0.05$ & $0.67 \pm 0.07$ & $0.08 \pm 0.16$ & $0.84 \pm 0.25$ & $1.76 \pm 0.52$ \\
\hline $5146 \mathrm{~S} 0012$ & $-0.22 \pm 0.38$ & $-0.01 \pm 0.07$ & $0.54 \pm 0.07$ & $0.07 \pm 0.14$ & $1.1 \pm 1.4$ & $2.3 \pm 2.8$ \\
\hline $5146 \mathrm{~S} 0013$ & $0.61 \pm 0.46$ & $0.02 \pm 0.07$ & $0.32 \pm 0.04$ & $0.16 \pm 0.14$ & $1.00 \pm 0.37$ & $2.16 \pm 0.75$ \\
\hline $5146 \mathrm{~S} 0014$ & $0.15 \pm 0.36$ & $-0.11 \pm 0.10$ & $0.18 \pm 0.03$ & $0.07 \pm 0.23$ & $0.80 \pm 0.35$ & $1.67 \pm 0.74$ \\
\hline $5146 \mathrm{~S} 0015$ & $-0.07 \pm 0.37$ & $0.01 \pm 0.05$ & $0.17 \pm 0.03$ & $0.08 \pm 0.05$ & $0.80 \pm 0.23$ & $1.68 \pm 0.46$ \\
\hline $5146 \mathrm{~S} 0016$ & $0.34 \pm 0.39$ & $-0.03 \pm 0.07$ & $0.29 \pm 0.04$ & $0.13 \pm 0.06$ & $1.38 \pm 0.57$ & $2.9 \pm 1.1$ \\
\hline $5146 \mathrm{~S} 0017$ & $0.36 \pm 0.40$ & $0.01 \pm 0.07$ & $0.36 \pm 0.04$ & $0.06 \pm 0.14$ & $0.91 \pm 0.32$ & $1.88 \pm 0.66$ \\
\hline $5146 \mathrm{~S} 0018$ & $0.22 \pm 0.38$ & $-0.17 \pm 0.09$ & $0.13 \pm 0.03$ & $-0.17 \pm 0.23$ & $0.96 \pm 0.35$ & $1.75 \pm 0.74$ \\
\hline $5146 \mathrm{~S} 0019$ & $0.20 \pm 0.39$ & $0.03 \pm 0.06$ & $0.29 \pm 0.04$ & $-0.03 \pm 0.18$ & $1.16 \pm 0.30$ & $2.29 \pm 0.63$ \\
\hline $5146 \mathrm{~S} 0020$ & $0.03 \pm 0.33$ & $-0.06 \pm 0.08$ & $0.11 \pm 0.03$ & $0.06 \pm 0.15$ & $1.01 \pm 0.30$ & $2.08 \pm 0.62$ \\
\hline
\end{tabular}




\begin{tabular}{|c|c|c|c|c|c|c|}
\hline \multicolumn{7}{|c|}{$\begin{array}{c}\text { TABLE B-2: } \\
\text { RADIONUCLIDE CONCENTRATION IN SOIL } \\
\text { LOWER LEVEL HILLSIDE AREA } \\
\text { SEPARATIONS PROCESS RESEARCH UNIT } \\
\text { NISKAYUNA, NEW YORK }\end{array}$} \\
\hline \multirow{2}{*}{ Sample ID ${ }^{a}$} & \multicolumn{6}{|c|}{ Radionuclide Concentration in Soil Samples (pCi/g) } \\
\hline & Sr-90 & Am-241 & Cs-137 & U-235 & U-238 & Total $U^{\mathrm{c}}$ \\
\hline $5146 \mathrm{~S} 0021$ & $0.35 \pm 0.39$ & $-0.02 \pm 0.08$ & $0.16 \pm 0.03$ & $0.22 \pm 0.15$ & $0.87 \pm 0.36$ & $1.96 \pm 0.74$ \\
\hline $5146 \mathrm{~S} 0022$ & $0.94 \pm 0.44$ & $-0.09 \pm 0.10$ & $0.56 \pm 0.07$ & $0.05 \pm 0.27$ & $1.36 \pm 0.48$ & $2.8 \pm 1.0$ \\
\hline $5146 \mathrm{~S} 0023$ & $0.17 \pm 0.37$ & $-0.01 \pm 0.06$ & $0.31 \pm 0.04$ & $0.18 \pm 0.17$ & $1.11 \pm 0.59$ & $2.40 \pm 1.19$ \\
\hline $5146 \mathrm{~S} 0024$ & $0.40 \pm 0.33$ & $0.03 \pm 0.08$ & $0.33 \pm 0.05$ & $0.09 \pm 0.17$ & $0.93 \pm 0.36$ & $1.95 \pm 0.74$ \\
\hline $5146 \mathrm{~S} 0025$ & $0.86 \pm 0.52$ & $0.01 \pm 0.08$ & $0.16 \pm 0.03$ & $-0.01 \pm 0.16$ & $1.25 \pm 0.39$ & $2.49 \pm 0.80$ \\
\hline $5146 S 0026$ & $0.17 \pm 0.39$ & $-0.09 \pm 0.12$ & $0.03 \pm 0.02$ & $0.26 \pm 0.28$ & $0.94 \pm 0.44$ & $2.14 \pm 0.92$ \\
\hline $5146 \mathrm{~S} 0027$ & $0.22 \pm 0.37$ & $-0.02 \pm 0.06$ & $0.09 \pm 0.02$ & $0.05 \pm 0.16$ & $1.02 \pm 0.31$ & $2.09 \pm 0.64$ \\
\hline $5146 S 0028$ & $0.35 \pm 0.36$ & $0.03 \pm 0.07$ & $0.07 \pm 0.02$ & $-0.07 \pm 0.15$ & $1.14 \pm 0.34$ & $2.21 \pm 0.70$ \\
\hline $5146 S 0029$ & $0.41 \pm 0.38$ & $-0.03 \pm 0.08$ & $0.49 \pm 0.06$ & $0.08 \pm 0.18$ & $1.00 \pm 0.39$ & $2.08 \pm 0.80$ \\
\hline $5146 \mathrm{~S} 0030$ & $0.56 \pm 0.39$ & $0.01 \pm 0.09$ & $0.39 \pm 0.06$ & $0.11 \pm 0.24$ & $1.05 \pm 0.43$ & $2.21 \pm 0.89$ \\
\hline $5146 \mathrm{~S} 0031$ & $0.22 \pm 0.33$ & $0.03 \pm 0.05$ & $0.32 \pm 0.04$ & $0.17 \pm 0.15$ & $0.84 \pm 0.24$ & $1.85 \pm 0.50$ \\
\hline $5146 \mathrm{~S} 0032$ & $0.26 \pm 0.34$ & $0.03 \pm 0.07$ & $0.65 \pm 0.08$ & $0.06 \pm 0.15$ & $1.04 \pm 0.70$ & $2.14 \pm 1.4$ \\
\hline $5146 \mathrm{~S} 0033$ & $0.38 \pm 0.34$ & $0.03 \pm 0.09$ & $1.09 \pm 0.10$ & $0.10 \pm 0.18$ & $1.27 \pm 0.39$ & $2.64 \pm 0.80$ \\
\hline $5146 \mathrm{~S} 0034$ & $0.31 \pm 0.32$ & $-0.02 \pm 0.07$ & $0.03 \pm 0.04$ & $0.17 \pm 0.19$ & $0.31 \pm 0.25$ & $0.79 \pm 0.53$ \\
\hline $5146 \mathrm{~S} 0035$ & $0.27 \pm 0.32$ & $0.08 \pm 0.06$ & $1.31 \pm 0.13$ & $0.12 \pm 0.19$ & $1.16 \pm 0.31$ & $2.44 \pm 0.65$ \\
\hline $5146 \mathrm{~S} 0036$ & $0.30 \pm 0.35$ & $-0.02 \pm 0.07$ & $0.08 \pm 0.02$ & $0.02 \pm 0.15$ & $1.40 \pm 0.35$ & $2.82 \pm 0.72$ \\
\hline
\end{tabular}

aRefer to Figures A-5.

bSr-90 concentration determination by analytical preparation and counted via low background proportional counter.

cTotal U is calculated by $\mathrm{U}-235+2 *$ ( U-238).

dUncertainties are at the $95 \%$ confidence level based on total propagated uncertainties.

eZero values for sample results are due to rounding. 


\begin{tabular}{|c|c|c|c|c|c|c|}
\hline \multicolumn{7}{|c|}{$\begin{array}{c}\text { TABLE B-3: } \\
\text { RADIONUCLIDE CONCENTRATION IN VEGETATION } \\
\text { LOWER LEVEL HILLSIDE AREA } \\
\text { SEPARATIONS PROCESS RESEARCH UNIT } \\
\text { NISKAYUNA, NEW YORK }\end{array}$} \\
\hline \multirow{2}{*}{ Sample ID ${ }^{a}$} & \multicolumn{6}{|c|}{ Radionuclide Concentration in Soil Samples (pCi/g) } \\
\hline & Sr-90 ${ }^{b}$ & Am-241 & Cs-137 & $\mathrm{U}-235$ & U-238 & Total $U^{c}$ \\
\hline 5146M0001 & $0.13 \pm 0.25^{\mathrm{d}}$ & $0.01 \pm 0.04$ & $0.06 \pm 0.04$ & $0.05 \pm 0.11$ & $-0.03 \pm 0.27$ & $-0.01 \pm 0.55$ \\
\hline $5146 \mathrm{M} 0002$ & $0.44 \pm 0.19$ & $0.01 \pm 0.04$ & $0.04 \pm 0.04$ & $-0.06 \pm 0.12$ & $0.02 \pm 0.27$ & $-0.02 \pm 0.55$ \\
\hline $5146 \mathrm{M} 0003$ & $-0.01 \pm 0.13$ & $0.00^{\mathrm{e}} \pm 0.05$ & $0.01 \pm 0.05$ & $0.03 \pm 0.11$ & $0.05 \pm 0.41$ & $0.13 \pm 0.82$ \\
\hline 5146M0004 & $0.32 \pm 0.20$ & $0.00 \pm 0.03$ & $0.05 \pm 0.03$ & $-0.12 \pm 0.14$ & $-0.08 \pm 0.19$ & $-0.28 \pm 0.40$ \\
\hline $5146 \mathrm{M} 0005$ & $0.32 \pm 0.17$ & $-0.01 \pm 0.04$ & $0.01 \pm 0.05$ & $0.01 \pm 0.17$ & $-0.12 \pm 0.34$ & $-0.23 \pm 0.70$ \\
\hline 5146M0006 & $0.06 \pm 0.11$ & $0.01 \pm 0.02$ & $0.02 \pm 0.02$ & $-0.08 \pm 0.08$ & $0.01 \pm 0.11$ & $-0.06 \pm 0.23$ \\
\hline 5146M0007 & $0.02 \pm 0.15$ & $0.01 \pm 0.03$ & $0.03 \pm 0.03$ & $0.14 \pm 0.10$ & $0.09 \pm 0.25$ & $0.32 \pm 0.51$ \\
\hline $5146 \mathrm{M} 0008$ & $0.37 \pm 0.34$ & $-0.01 \pm 0.02$ & $0.42 \pm 0.03$ & $0.04 \pm 0.03$ & $0.74 \pm 0.12$ & $1.52 \pm 0.24$ \\
\hline 5146M0009 & $0.39 \pm 0.24$ & $-0.02 \pm 0.03$ & $0.11 \pm 0.02$ & $0.06 \pm 0.07$ & $0.09 \pm 0.25$ & $0.24 \pm 0.50$ \\
\hline 5146M0010 & $1.01 \pm 0.28$ & $0.01 \pm 0.02$ & $0.08 \pm 0.02$ & $-0.05 \pm 0.09$ & $0.09 \pm 0.13$ & $0.13 \pm 0.28$ \\
\hline $5146 \mathrm{M} 0011$ & $0.09 \pm 0.15$ & $0.01 \pm 0.07$ & $0.04 \pm 0.08$ & $0.16 \pm 0.17$ & $-0.26 \pm 0.62$ & $-0.4 \pm 1.3$ \\
\hline 5146M0012 & $0.21 \pm 0.09$ & $-0.03 \pm 0.02$ & $0.01 \pm 0.01$ & $0.02 \pm 0.07$ & $0.07 \pm 0.17$ & $0.16 \pm 0.35$ \\
\hline
\end{tabular}

aRefer to Figure A-6

bSr-90 concentration determination by analytical preparation and counted via low background proportional counter.

cTotal U is calculated by $\mathrm{U}-235+2 *(\mathrm{U}-238)$.

dUncertainties are at the $95 \%$ confidence level based on total propagated uncertainties.

eZero values for sample results are due to rounding. 


\section{APPENDIX C MAJOR INSTRUMENTATION}


The display of a specific product is not to be construed as an endorsement of the product or its manufacturer by the author or his employer.

\section{C.1 SCANNINg AND MEASUREMENT InSTRUMENT/Detector Combinations}

Ludlum Scintillation Detector Model SPA-3, Crystal: 2-in. x 2-in. (Ludlum Measurements, Inc., Sweetwater, TX)

Coupled to:

Ludlum Ratemeter-Scaler Model 2221 (Ludlum Measurements, Inc., Sweetwater, TX)

Coupled to:

Trimble GeoXH Receiver and Data Logger (Trimble Navigation Limited, Sunnyvale, CA)

Ludlum Beta Scintillation Detector Model 44-142, 1.125-in. diameter magnetically shielded photomultiplier. (Ludlum Measurements, Inc., Sweetwater, TX)

Coupled to:

Ludlum Ratemeter-Scaler Model 2221 (Ludlum Measurements, Inc., Sweetwater, TX)

\section{C.2 LABORATORY ANALYTICAL INSTRUMENTATION}

High-Purity Extended Range Intrinsic Detector CANBERRA/Tennelec Model No: ERVDS30-25195 (Canberra, Meriden, CT)

Used in conjunction with:

Lead Shield Model G-11 (Nuclear Lead, Oak Ridge, TN), Apex Gamma Software (Canberra, Meriden, CT) and Multichannel Analyzer with Dell Workstation

High-Purity Extended Range Intrinsic Detector Model No. GMX-45200-5 (AMETEK/ORTEC, Oak Ridge, $\mathrm{TN}$ )

Used in conjunction with:

Lead Shield Model SPG-16-K8 (Nuclear Data), Apex Gamma Software (Canberra, Meriden, CT) and Multichannel Analyzer with Dell Workstation

High-Purity Germanium Detector Model GMX-30-P4, 30\% Eff. (AMETEK/ORTEC,

Oak Ridge, $\mathrm{TN}$ )

Used in conjunction with:

Lead Shield Model G-16 (Gamma Products, Palos Hills, IL), Apex Gamma Software (Canberra, Meriden, CT) and Multichannel Analyzer with Dell Workstation

Low background alpha/beta counting system

Canberra/Tennelec LB5100W

Eclipse Software

(Canberra, Inc., Meriden, CT) 


\section{APPENDIX D \\ SURVEY AND ANALYTICAL PROCEDURES}




\section{D.1 Project Health AND SAFETy}

Personnel working on the project were provided by URS-SPRU representatives site-specific safety awareness training to ensure that appropriate safety precautions were implemented. Pre-survey activities included an overview of potential health and safety issues. Survey activities were conducted in accordance with the ORAU/ORISE overall health and safety program (HASP) and radiological protection program manuals (ORAU 2011b and ORISE 2011c). Potential health and safety issues were appropriately addressed by the ORISE HASP, site-specific Integrated Safety Management (ISM) pre-job hazard checklist, and an activity hazard analysis (AHA) prior to beginning site work.

\section{D.2 Quality Assurance}

Analytical and field survey activities were conducted in accordance with procedures from the following ORAU and ORISE documents:

- Survey Procedures Manual (ORISE 2008)

- Laboratory Procedures Manual (ORISE 2011b)

- Quality Program Manual (ORAU 2011a)

The procedures contained in these manuals were developed to meet the requirements of 10 CFR 830 Subpart A, Quality Assurance Requirements, Department of Energy Order 414.1C, Quality Assurance, and the U.S. Nuclear Regulatory Commission, Quality Assurance Manual for the Office of Nuclear Material Safety and Safeguards, and contain measures to assess processes during their performance.

Quality control procedures include:

- Daily instrument background and check-source measurements to confirm that equipment operation is within acceptable statistical fluctuations.

- Participation in Mixed Analyte Performance Evaluation Program (MAPEP), National Institute for Standards and Technology (NIST) Radiochemistry Intercomparison Program (NRIP), and Intercomparison Testing Program (ITP) Laboratory Quality Assurance Programs.

- Training and certification of all individuals performing procedures.

- Periodic internal and external audits. 


\section{D.3 CALIBRATiON}

Calibration of all field and laboratory instrumentation was based on standards/sources, traceable to NIST, when such standards/sources were available. In cases where they were not available, standards of an industry-recognized organization were used.

\section{D.4 Survey Procedures}

\section{D.4.1 Surface Scans}

Scans for elevated gamma radiation were performed by passing the detector slowly over the surface. The distance between the detector and surface was maintained at a nominal of about 1 to 5 centimeters $(\mathrm{cm})$. NaI scintillation detectors were coupled to GPS units that enabled real-time recording of position in one-second intervals. Identification of elevated radiation levels was based on increases in the audible signal from the instrument. Positioning data files were downloaded from field data loggers for plotting using commercially available software (http://trl.trimble.com/docushare/dsweb/Get/Document261826/GeoExpl2005 100A GSG ENG.pdf).

The scan minimum detectable concentrations (MDCs) for the $\mathrm{NaI}$ scintillation detector for the contaminants of concern in surface soil were obtained directly from NUREG- $1507^{1}$ when available or estimated using the calculation approach described in NUREG-1507. A typical NaI 2-inch by 2-inch detector MDC is $6.4 \mathrm{pCi} / \mathrm{g}$ for cesium-137. Audible increases in the activity rate are investigated by ORISE. It is standard procedure for ORISE staff to pause and investigate any locations where gamma radiation is distinguishable from background levels.

\section{D.4.2 Surface Activity Measurements}

Measurements of total beta surface activity levels were performed using hand-held scintillation detectors coupled to portable ratemeter-scalers. Count rates (cpm), which were integrated over one minute with the detector held in a static position, were converted to activity levels $\left(\mathrm{dpm} / 100 \mathrm{~cm}^{2}\right)$ by dividing the count rate by the total static efficiency $\left(\varepsilon_{\mathrm{i}} \times \varepsilon_{\mathrm{s}}\right)$ and correcting for the physical area of the detector.

${ }^{1}$ NUREG-1507. Minimum Detectable Concentrations With Typical Radiation Survey Instruments for Various Contaminants and Field Conditions. U.S. Nuclear Regulatory Commission. Washington, DC; June 1998. 
The a priori $\mathrm{MDC}$ for surface activity measurements was calculated using the following equation:

$$
M D C=\frac{3+(4.65 \sqrt{B})}{T x \varepsilon_{T o t} x G}
$$

Where:

$\begin{array}{lll}\mathrm{B} & = & \text { background (total counts) in time interval, } \mathrm{T} \\ \mathrm{T} & = & \text { count time (min) used for field instruments } \\ \varepsilon_{\mathrm{Tot}} & = & \text { total efficiency }=\varepsilon_{\mathrm{i}} \times \varepsilon_{\mathrm{s}} \\ \varepsilon_{\mathrm{i}} & = & \text { instrument efficiency } \\ \varepsilon_{\mathrm{s}} & = & \text { source efficiency } \\ \mathrm{G} & = & \left.\text { geometry (physical detector area } \mathrm{cm}^{2} / 100\right)\end{array}$

The physical surface area assessed by the scintillation detector used was $100 \mathrm{~cm}^{2}$. The a priori beta static MDC was approximately $281 \mathrm{dpm} / 100 \mathrm{~cm}^{2}$ using the total efficiency of 0.32 and the site redetermined instrument background of $349 \mathrm{cpm}$.

\section{D.4.2 Soil Sampling}

Approximately 0.5 to 1 kilogram of soil was collected at each sample location. Collected samples were placed in plastic bags, sealed, and labeled in accordance with ORISE survey procedures.

\section{D.4.3 Vegetation Sampling}

Approximately a 1 kilogram sample was collected at each location was placed in large plastic bags, sealed, and labeled in accordance with ORISE survey procedures. Vegetation samples were washed to remove particles, which may contain radionuclide contamination, from the outer surface. The wet weight of the sample was determined. For non volatile radionuclides the samples were dried. The ratio of wet to dry weight was calculated prior to additional analysis.

\section{D.5 RAdiological ANALysis}

\section{D.5.1 Detection Limits}

Detection limits, referred to as MDC, were based on 3 plus 4.65 times the standard deviation of the background count $\left[3+\left(4.65(\mathrm{BKG})^{1 / 2}\right)\right]$. Because of variations in background levels, measurement efficiencies, and contributions from other radionuclides in samples, the detection limits differ from sample to sample and instrument to instrument. 


\section{D.5.2 STRONTIUM-90}

Soil and vegetation samples were dissolved by a combination of potassium hydrogen fluoride and pyrosultfate fusions. The fusion cake was dissolved and strontium was coprecipitated on lead sulfate. The strontium was separated from residual calcium and lead by precipitating strontium sulfate from ethylenediaminetetraacetic acid at a $\mathrm{pH}$ of 4.0. Strontium was separated from barium by complexing the strontium in diethylenetriaminepentaacetic acid while precipitating barium as barium carbonate. The strontium was ultimately converted to strontium carbonate and counted on a low-background gas proportional counter. The typical MDC of the procedure is $0.4 \mathrm{pCi} / \mathrm{g}$ for a one hour count time.

\section{D.5.3 Gamma Spectroscopy}

Samples of soil and vegetation were dried, mixed, crushed, and/or homogenized as necessary, and a portion sealed in a 0.5 -liter Marinelli beaker or other appropriate container. The quantity placed in the beaker was chosen to reproduce the calibrated counting geometry. Net material weights were determined and the samples counted using intrinsic germanium detectors coupled to a pulse height analyzer system. Background and Compton stripping, peak search, peak identification, and concentration calculations were performed using the computer capabilities inherent in the analyzer system. All TAPs associated with the radionuclides of concern were reviewed for consistency of activity. Total absorption peaks used for determining the activities of radionuclides of concern and the typical associated MDCs for a one-hour count time were:

\begin{tabular}{|c|c|c|}
\hline Radionuclide $^{\mathrm{a}}$ & TAP (MeV) & MDC (pCi/g) \\
\hline Cs-137 & 0.662 & 0.05 \\
\hline Am-241 & 0.059 & 0.11 \\
\hline U-235 b & 0.144 & 0.24 \\
\hline U-238c & 0.063 & 0.75 \\
\hline
\end{tabular}

aSpectra were also reviewed for other identifiable TAPs.

bThe $143.76 \mathrm{keV}$ peak is used for the quantification of U-235 in the presence of Ra.

cThe $63.29 \mathrm{keV}$ peak is from Th-234, the first progeny of U-238 and is used to quantify U-238.

\section{D.5.4 Uncertainties}

The uncertainties associated with the analytical data presented in the tables of this report represent the total propagated uncertainties for those data. These uncertainties were calculated based on both the gross sample count levels and the associated background count level. 